\title{
The impact of urban gardens on adequate and healthy food: a systematic review
}

\author{
Mariana T Garcia ${ }^{1, *}$, Silvana M Ribeiro ${ }^{1}$, Ana Claudia Camargo Gonçalves Germani ${ }^{2}$ \\ and Cláudia M Bógus ${ }^{1}$ \\ 'Department of Public Health Practice, School of Public Health, University of São Paulo, Av. Dr Arnaldo 715, Room \\ 7, CEP 01246-904, São Paulo, SP, Brazil: ${ }^{2}$ Department of Preventive Medicine, University of São Paulo Medical \\ School, São Paulo, SP, Brazil
}

Submitted 1 July 2016: Final revision received 19 August 2017: Accepted 29 August 2017: First published online 21 November 2017

\begin{abstract}
Objective: To examine the impacts on food and nutrition-related outcomes resulting from participation in urban gardens, especially on healthy food practices, healthy food access, and healthy food beliefs, knowledge and attitudes.

Design: The systematic review identified studies by searching the PubMed, ERIC, LILACS, Web of Science and Embase databases. An assessment of quality and bias risk of the studies was carried out and a narrative summary was produced.

Setting: Studies published as original articles in peer-reviewed scientific journals in English, Spanish or Portuguese between 2005 and 2015 were included.

Subjects: The studies included were based on data from adult participants in urban gardens.

Results: Twenty-four studies were initially selected based on the eligibility criteria, twelve of which were included. There was important heterogeneity of settings, population and assessment methods. Assessment of quality and bias risk of the studies revealed the need for greater methodological rigour. Most studies investigated community gardens and employed a qualitative approach. The following were reported: greater fruit and vegetable consumption, better access to healthy foods, greater valuing of cooking, harvest sharing with family and friends, enhanced importance of organic production, and valuing of adequate and healthy food.

Conclusions: Thematic patterns related to adequate and healthy food associated with participation in urban gardens were identified, revealing a positive impact on practices of adequate and healthy food and mainly on food perceptions.
\end{abstract}

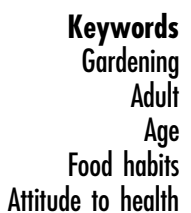

The literature in the field of public health has reported numerous health benefits associated with greater consumption of fruit and vegetables (F\&V) and lower consumption of ultra-processed foods ${ }^{(1,2)}$. The individual's ability to make healthy food choices is determined by the foods available and accessible. Interventions that can influence food-related processes, such as urban gardens, help promote healthy choices. Access to urban gardens appears to be an important determinant of local availability of $F \& V^{(3)}$. Therefore, the objective of the present review was to identify and summarize studies that have reported the influence of participation in urban gardens on food and nutrition-related outcomes.

Studies have reported that daily F\&V intake promotes health $^{(4)}$. The WHO recommends a minimum consumption of $400 \mathrm{~g}$ of $\mathrm{F} \& \mathrm{~V}$ daily to prevent chronic diseases, such as CVD, cancer, diabetes type 2 and obesity ${ }^{(5)}$. However, a large proportion of the world's population has low F\&V intake. Data on 196373 adults from fifty-two low- and middle-income countries showed that about $78 \%$ of men and women fail to meet the WHO daily recommended intake of $\mathrm{F} \& \mathrm{~V}^{(6)}$. Empirical evidence on environmental influences on $\mathrm{F} \& \mathrm{~V}$ consumption indicates that good local availability, such as access to gardens, appears to have a positive influence on consumption ${ }^{(3)}$.

In the last 20 years, the community gardening movement has grown rapidly in many countries and, together with producers' markets, organic markets, slow food, fair trade and food cooperatives, among others, it forms the Food Movement driven by the community at large ${ }^{(7)}$. Food Movement can be understood as an urban social movement that struggles to identify eaters primarily as citizens as 
opposed to consumers, and it promotes a food security strategy $^{(7,8)}$. Community gardens, in the Food Movement context, can offer 'opportunities for collective learning about food security, environmental sustainability, community resilience, social justice and cultural identity ${ }^{\text {(7) }}$. Recent research has been increasingly addressing the influence of urban gardening, both community gardens and domestic gardens, on a variety of outcomes, such as quality of life and physical activity ${ }^{(9)}$, mental health ${ }^{(10)}$, social relationships and sense of belonging to the community $^{(11,12)}$, income generation ${ }^{(13)}$, social inclusion ${ }^{(14)}$, self-reliance and empowerment ${ }^{(15)}$, and practising and sharing knowledge and skills with others ${ }^{(12)}$, among other benefits.

A close relationship between urban gardens and food and nutrition is evident, given that most garden-grown produce is meant for own consumption, sharing or sale at local markets, thus bringing benefits not only to the participants but also to the community ${ }^{(16)}$. Although results have already been reported on broader food-related outcomes, such as contribution to food security through enhanced access to culturally appropriate foods ${ }^{(12)}$, increased consumption of $\mathrm{F} \& \mathrm{~V}$ is the most prevalent dietary outcome found in the literature and has been frequently reported for school gardens ${ }^{(17-19)}$. Considering that a growing number of scientific studies involve urban gardening, a substantial and heterogeneous body of literature is now available on food and nutrition outcomes in adults from experiences with urban gardens. Two systematic reviews on urban gardening and various dimensions of dietary outcomes conducted in recent years were found in the literature. However, both of these studies involved children and youth ${ }^{(20,21)}$, hence there is a gap in studies in adults. Robinson-O'Brien et al. ${ }^{(20)}$, assessing the impact of garden-based youth nutrition intervention programmes on nutrition-related outcomes, reported increased willingness to try $\mathrm{F} \& \mathrm{~V}$, improved knowledge on nutrition, greater probability of cooking and other outcomes. Masset et $a l^{(21)}$, in a study that assessed the effectiveness of agricultural interventions for improving the nutritional status of children and other intermediate outcomes in developing countries, reported positive effects on dietary composition, with higher production and consumption of healthy foods.

To date, no systematic reviews have been published on which dimensions of food and nutrition-related outcomes are being reported in adults. Thus, the objective of the present literature review was to identify the impacts on food and nutrition-related outcomes of participation in urban gardens, and to use these data to answer the following research questions:

1. Is participation in urban gardens positively associated with healthy food practices?

2. Is participation in urban gardens positively associated with healthy food access?
3. Is participation in urban gardens positively associated with healthy food beliefs, knowledge and attitudes?

Additionally, we used the results to assess whether the associations reported between participation in urban gardens and food and nutrition-related outcomes vary by type of study, type of garden (community or domestic) or population health status.

\section{Methods}

The current systematic review is reported using the PRISMA (Preferred Reporting Items for Systematic Reviews and Meta-Analyses) writing guidelines to guarantee the quality of the research process and assure transparent reporting of the review.

\section{Selection criteria}

The PICO (Population, Intervention, Comparison, and Outcome) method was used to devise the following research question for the systematic review: "What is the influence of participation of adults in urban gardens on food and nutrition-related outcomes? ${ }^{(22)}$.

For inclusion in the review, studies had to meet the following eligibility criteria: (i) study published as an original article in a peer-reviewed scientific journal in English, Spanish or Portuguese between 2005 and 2015; (ii) study population comprising adults living in urban areas, irrespective of whether other age groups were involved; (iii) study objective of participation in urban gardens; and (iv) assessing or reporting food-related outcomes in the contexts of health promotion and food security. For the purposes of the review, healthy diet was defined as a determinant of health, diet was considered culturally and socially constructed, and the dimensions of social determinants, access, environment and food systems were addressed ${ }^{(23-25)}$.

\section{Information sources}

Five databases were used for the search conducted between January and February 2016: PubMed, LILACS, ERIC, Embase and Web of Science. Experts in the field of urban agriculture were asked, both by email and personally, to identify studies that might meet the inclusion criteria. Lastly, the reference lists of the selected articles were hand-checked.

\section{Search}

The search strategy consisted of descriptors of each database relative to intervention AND population AND outcome. In accordance with PRISMA guidelines, the search strategy used in each database included in the systematic review is given in the online supplementary material, Supplemental Table 1. 


\section{Study selection}

With the aid of EndNote ${ }^{\mathrm{TM}}$ reference manager, all hits were organized and duplications removed. By applying the previously outlined eligibility criteria, the articles were independently selected by two reviewers (M.T.G., S.M.R.), both with prior experience in food security and health promotion. Titles and abstracts of the articles were first selected to satisfy the selection criteria. Discrepancies were subsequently discussed based on reading of the full texts until a consensus was reached. Disagreements on inclusion were decided by a third examiner (C.M.B.). Finally, the potentially eligible studies were assessed by reading of the full texts.

\section{Data extraction}

Data extraction from the selected articles was undertaken by one of the authors and the completed spreadsheet, which had been designed to answer the research question, checked by another author to ensure accuracy and scope. The following information was extracted: (i) publication details (authors, year of publication); (ii) location; (iii) objective; (iv) design (duration); (v) participation; (vi) outcomes investigated; (vii) method of measuring outcomes; (viii) food and nutrition-related outcomes; and (ix) study quality, as assessed using the COREQ ${ }^{(26)}$ (Consolidated Criteria for Reporting Qualitative Research) for qualitative studies and using the instruments of the National Institutes of Health ${ }^{(27)}$ for quantitative studies.

The COREQ ${ }^{(2)}$ is a thirty-two-item checklist for interviews and focus groups comprising three domains: 'research team and reflexivity' (eight items), 'study design' (fifteen items) and 'analysis and findings' (nine items). The following instruments of the National Institutes of Health ${ }^{(27)}$ were used: Quality Assessment Tool for Before-After (Pre-Post) Studies With No Control Group (twelve items) and Quality Assessment Tool for Observational Cohort and CrossSectional Studies (fourteen items). The following quality ratings were attributed to the studies: 'strong' where $66 \%$ or more of the quality assessment criteria were satisfied; 'moderate' when 33-65\% of criteria were satisfied; and 'weak' when $32 \%$ or less of the criteria were satisfied.

One of the studies used qualitative and quantitative approaches, and in this case quality assessment of both components was performed. Qualitative component ratings were decided by consensus because they were used to assess food-related outcomes. Inconsistencies in ratings were subsequently discussed until a consensus was reached.

\section{Summary of results}

Owing to the heterogeneous nature of the included studies, a narrative summary of included studies was prepared. The study outcomes were not directly comparable; therefore studies were read and the food and nutritionrelated dimensions reported in the study outcomes were subsequently identified. Differences and commonalities between study results were identified, collated and described narratively. Statistically significant and non-significant results were reported.

\section{Results}

\section{Study selection}

The search of the databases led to the retrieval of 807 studies (five in LILACS, 409 in PubMed, 338 in Embase, nine in ERIC and forty-six in the Web of Science). A further ten articles - derived from indication by researchers or hand-searching of the list of references of relevant studies - were also included. After exclusion of 158 duplications, 660 articles were considered eligible for the next stage of selection. Based on titles and abstracts, twenty-eight articles were short-listed for reading of their full texts. Sixteen publications were excluded because they did not meet the inclusion criteria; thus, a total of twelve articles were included in the present systematic review $^{(28-39)}$. Figure 1 shows the study selection process and the related flowchart.

\section{Study characteristics}

The majority of the studies involved existing gardens while only four studies assessed interventions ${ }^{(28-30,33)}$. Of these interventions, three had pre- and post-intervention without a control group, and one was a cross-sectional qualitative study. The eight studies on existing gardens were observational, comprising seven cross-sectional (three quantitative and four qualitative) studies and one cohort study. The sample size of the studies varied considerably, ranging from twelve to 855 participants.

Table 1 provides an overview of the main characteristics of the twelve studies included in the current review.

The reported results were grouped into three categories representing food and nutrition-related dimensions: 'healthy food practices', 'healthy food access' and 'healthy food beliefs, knowledge and attitudes'. The studies and their outcomes by nutrition-related dimension are given in Table 2 .

\section{Studies reporting outcomes on bealtby food practices}

Seven studies reported outcomes on healthy food practices. Studies that reported outcomes on this dimension addressed increases in the amount and variety of $F \& V$ consumed ${ }^{(29,31,33-35,37,39)}$, practice of a healthier diet ${ }^{(29,33)}$ and improved nutrition of the family ${ }^{(29,34)}$.

The study of Blair et al. ${ }^{(29)}$ reported an increase in intake of $\mathrm{F} \& \mathrm{~V}$ servings/d and a positive impact on the family diet. Hale et al. ${ }^{(31)}$ reported that participation in the gardens increased the amount and variety of vegetables consumed. Spees et al. ${ }^{(33)}$ revealed greater consumption of fresh foods, exposure to foods not previously tried, a 


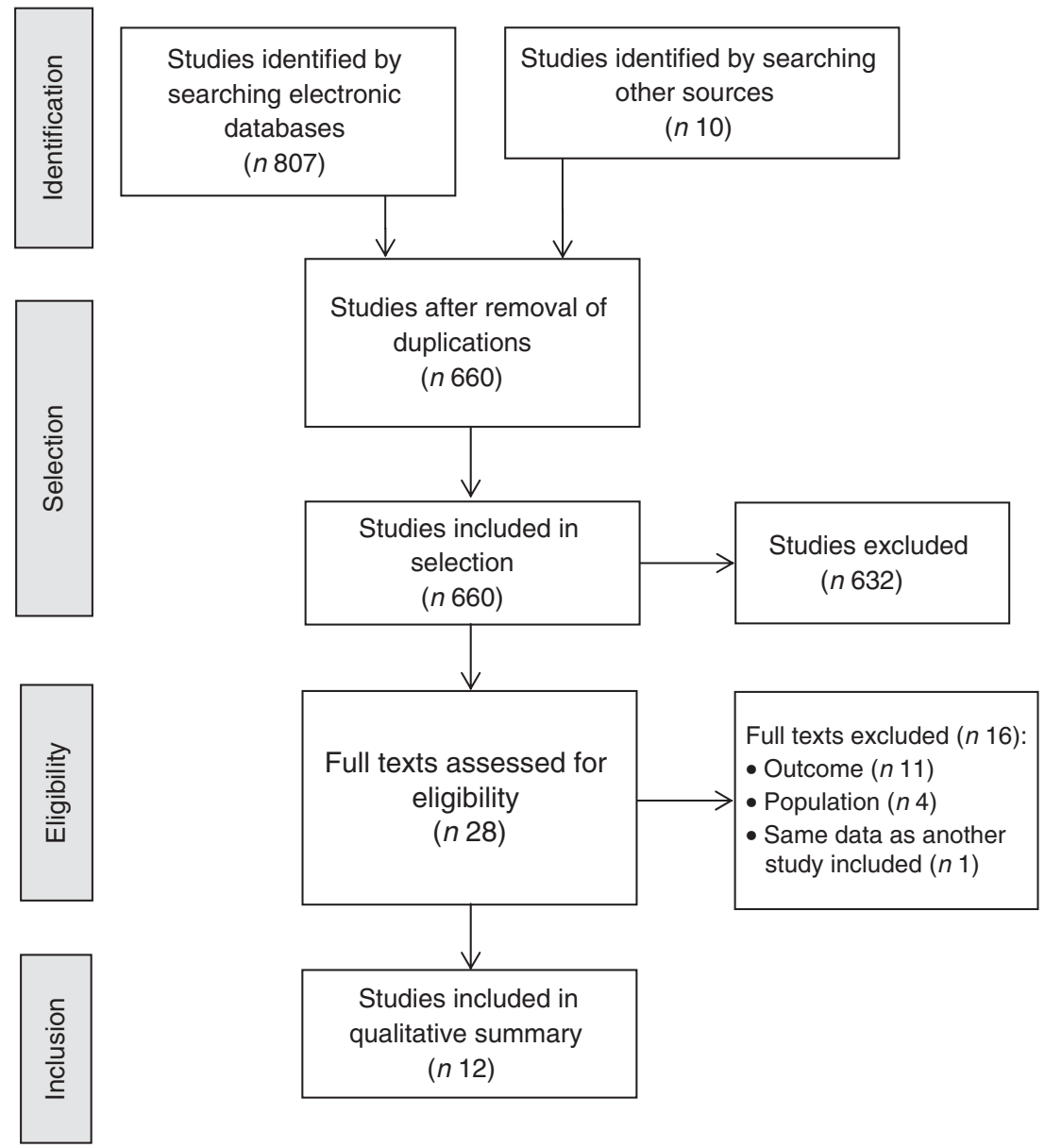

Fig. 1 Flowchart of the study selection process in the current review on the impact of urban gardens on adequate and healthy food

more varied diet, and reduced consumption of red meat and ultra-processed foods. Wakefield et al. ${ }^{(34)}$ reported improved nutrition of the children and their family, and greater consumption of vegetables. Alaimo et al. $^{(35)}$ showed that individuals consumed F\&V more times per day and were more likely to have consumed the recommended intake. Litt et $a l^{(37)}$ showed higher F\&V intake and a greater proportion of individuals consuming the recommended five daily servings. McMahan et al. ${ }^{(39)}$ found that experience with gardening had a statistically significant relationship with F\&V intake.

Studies of Weltin and Lavin ${ }^{(28)}$, Giraldo et al. ${ }^{(30)}$, Scott et $a l^{(32)}$, Wills et $a l^{(36)}$ and Freeman et al. ${ }^{(38)}$ did not report outcomes on healthy food practices.

Studies reporting outcomes on bealtby food access Eight studies reported outcomes on healthy food access. The studies that reported outcomes on this dimension addressed increasing access to healthy foods ${ }^{(28,30-32,34,36,38)}$, sharing produce ${ }^{(31,32,34,36,38,39)}$ and reducing food costs ${ }^{(32,34,38)}$.

In the study by Weltin and Lavin ${ }^{(28)}$, participants reported increased access to healthy foods, whereas Giraldo et al. ${ }^{(30)}$ noted an increase in availability of vegetable produce.
Participants in the investigation of Hale et $a l^{(31)}$ regarded the foods grown as something to be shared with individuals and charities, in addition to reporting improved access to foods. Results of the study by Scott et al. ${ }^{(32)}$ showed that producing fresh $\mathrm{F} \& \mathrm{~V}$ was one of the main reasons for gardening, where produce was for own consumption or to share with others. Other reasons for growing F\&V included reducing food costs, as well as the satisfaction of sharing foods with friends and family members. Wakefield et al. ${ }^{(34)}$ reported better access to fresh and healthy foods, savings on food costs and sharing of foods. Wills et al. ${ }^{(36)}$ described greater access to vegetables and harvest sharing, while Freeman et al. ${ }^{(38)}$ reported the strengthening of ties with neighbours through sharing foods grown and also the financial benefits of growing one's own food. Individuals interviewed by McMahan et al. ${ }^{(39)}$ reported F\&V sharing.

Studies of Blair et $a l .{ }^{(29)}$, Spees et $a l .{ }^{(33)}$, Alaimo et $a l .{ }^{(35)}$ and Litt et $a l^{(37)}$ did not report outcomes on healthy food access.

\section{Studies reporting outcomes on bealthy food beliefs, knowledge and attitudes}

Nine studies reported outcomes on healthy food beliefs, knowledge and attitudes. Studies that reported outcomes 
Table 1 Characterization of studies regarding the impact of participation in urban gardens on food-related outcomes in the context of health promotion and food security, and key results

\begin{tabular}{|c|c|c|c|c|c|c|c|c|}
\hline $\begin{array}{l}\text { Data on publication } \\
\text { (authors, year of } \\
\text { publication and } \\
\text { journal) }\end{array}$ & Setting & Objective & Design & Participants & Outcomes investigated & $\begin{array}{l}\text { Outcome measurement } \\
\text { method }\end{array}$ & $\begin{array}{l}\text { Food-related outcomes in the } \\
\text { context of health promotion and } \\
\text { food security }\end{array}$ & $\begin{array}{l}\text { Quality } \\
\text { rating }\end{array}$ \\
\hline $\begin{array}{l}\text { Weltin and Lavin }{ }^{(28)} \\
2012 \\
\text { Journal of } \\
\text { Community } \\
\text { Health Nursing }\end{array}$ & $\begin{array}{l}\text { Dubuque, IA, } \\
\text { USA }\end{array}$ & $\begin{array}{l}\text { To explore the relationship } \\
\text { between CG participation } \\
\text { and HgA1c levels, physical } \\
\text { activity and healthy food } \\
\text { sources among diabetics }\end{array}$ & $\begin{array}{l}\text { Pre- and post-intervention } \\
\text { study with no control group }\end{array}$ & $\begin{array}{l}13 \text { adult diabetic patients } \\
\text { from a health centre }\end{array}$ & $\begin{array}{l}\text { Quantitative outcomes: BMI, } \\
\text { HgA1c, lipids and blood } \\
\text { pressure. Qualitative } \\
\text { outcomes: cultural norms } \\
\text { and beliefs. Barriers to } \\
\text { dietary care and } \\
\text { perception }\end{array}$ & $\begin{array}{l}\text { Quantitative: collection of } \\
\text { weight, height, blood and } \\
\text { arterial pressure. } \\
\text { Qualitative: observation } \\
\text { and field notes during } \\
\text { weekly activities with } \\
\text { participants }\end{array}$ & $\begin{array}{l}\text { Increased access to healthy } \\
\text { foods; greater interest in } \\
\text { recipes and methods of } \\
\text { preparing foods grown; } \\
\text { significant reduction in HgA1c } \\
\text { levels }\end{array}$ & Strong \\
\hline $\begin{array}{l}\text { Blair et al. } \\
2013 \\
\text { Acta Oncologica }\end{array}$ & $\underset{\text { BSA }}{\text { Birmingham, AL, }}$ & $\begin{array}{l}\text { To explore the effects of a } \\
\text { domestic gardening } \\
\text { training intervention on } \\
\text { F\&V, physical activity, } \\
\text { quality of life and physical } \\
\text { function }\end{array}$ & $\begin{array}{l}\text { Pre- and post-intervention } \\
\text { study with no control group }\end{array}$ & $\begin{array}{l}12 \text { cancer survivors ( } 8 \text { adults } \\
\text { and } 4 \text { children) and } 4 \text { adult } \\
\text { guardians of the children }\end{array}$ & $\begin{array}{l}\text { BMI, F\&V intake, quality of } \\
\text { life, perception of effects of } \\
\text { the intervention on diet, } \\
\text { physical activity, medical } \\
\text { conditions, physical } \\
\text { functions, sun exposure, } \\
\text { intention to tend another } \\
\text { garden }\end{array}$ & $\begin{array}{l}\text { Questionnaires, physical } \\
\text { function test, } \\
\text { measurement of weight, } \\
\text { height, biomarkers, } \\
\text { structured interview with } \\
\text { open questions }\end{array}$ & $\begin{array}{l}\text { Increased F\&V intake; overall } \\
\text { increase in serum carotenoid } \\
\text { concentration; greater } \\
\text { motivation to follow a healthier } \\
\text { diet generally and consume } \\
\text { more vegetables specifically; } \\
\text { impact on family diet; greater } \\
\text { interest in a healthy diet for life } \\
\text { cycle }\end{array}$ & Strong \\
\hline $\begin{array}{l}\text { Giraldo et al. }{ }^{(30)} \\
2012 \\
\text { Avances en } \\
\text { Enfermería }\end{array}$ & Tunja, Colombia & $\begin{array}{l}\text { To design, implement and } \\
\text { assess an intervention } \\
\text { strategy }\end{array}$ & $\begin{array}{l}\text { Pre- and post-intervention } \\
\text { study with no control group }\end{array}$ & $\begin{array}{l}13 \text { education agents and } 6 \\
\text { adult family users of the } \\
\text { social programme }\end{array}$ & $\begin{array}{l}\text { Meanings, benefits, errors, } \\
\text { recommendations and } \\
\text { mechanisms of continuing } \\
\text { the intervention }\end{array}$ & NR & $\begin{array}{l}\text { Increased availability of garden } \\
\text { produce; participants became } \\
\text { knowledge multipliers within } \\
\text { their families and communities; } \\
\text { assimilation of knowledge on } \\
\text { adequate and healthy food and } \\
\text { principles of urban agriculture }\end{array}$ & Weak \\
\hline $\begin{array}{l}\text { Hale et al. } \\
\quad 2011 \\
\text { Social Science \& } \\
\quad \text { Medicine }\end{array}$ & $\begin{array}{l}\text { Denver, CO, } \\
\text { USA }\end{array}$ & $\begin{array}{l}\text { To understand the aesthetic } \\
\text { experience of } C G \text { as a } \\
\text { means to facilitate } \\
\text { ecological learning, the } \\
\text { affirmation and expression } \\
\text { of aesthetic, cultural and } \\
\text { individual values, and the } \\
\text { impact of these processes } \\
\text { on health }\end{array}$ & $\begin{array}{l}\text { Observational, cross- } \\
\text { sectional study }\end{array}$ & $\begin{array}{l}67 \text { adult participants in urban } \\
\text { gardens }\end{array}$ & $\begin{array}{l}\text { Meaning and history of } C G \text {, } \\
\text { social aspects of } C G \\
\text { participation, relationship } \\
\text { in CG, reasons for } C G \\
\text { participation, experience } \\
\text { in } C G \text {, whether } \\
\text { participants introduced } \\
\text { others to CG, perceptions } \\
\text { of meaning of CG for } \\
\text { participants and non- } \\
\text { participants, and } \\
\text { perceptions regarding } \\
\text { benefits of } C G\end{array}$ & Interviews and focus groups & $\begin{array}{l}\text { Foods grown were shared with } \\
\text { individuals and charities; } \\
\text { garden-grown foods were } \\
\text { 'better', more flavoursome, } \\
\text { fresher and more desirable; } \\
\text { valuing of organic production; } \\
\text { greater amount and variety of } \\
\text { vegetables consumed; } \\
\text { connection with cultural roots; } \\
\text { establishment of relationship } \\
\text { with foods that served to } \\
\text { support healthy eating } \\
\text { behaviours }\end{array}$ & Strong \\
\hline $\begin{array}{l}\text { Scott et al. }{ }^{(32)} \\
2014 \\
\text { Ageing and Society }\end{array}$ & $\begin{array}{l}\text { St Lucia, QLD, } \\
\text { Australia }\end{array}$ & $\begin{array}{l}\text { To identify the reasons for } \\
\text { practising gardening and } \\
\text { the resultant benefits of } \\
\text { the activity }\end{array}$ & $\begin{array}{l}\text { Observational, cross- } \\
\text { sectional study }\end{array}$ & 331 older adults who had DG & $\begin{array}{l}\text { Main reason for practising } \\
\text { gardening, benefits of the } \\
\text { practice, adaptation of } \\
\text { gardening activities with } \\
\text { ageing, main activities } \\
\text { performed in the garden }\end{array}$ & $\begin{array}{l}\text { Completion of questionnaires } \\
\text { online or by email }\end{array}$ & $\begin{array}{l}\text { Production of fresh, pesticide-free } \\
F \& V \text { for own consumption and } \\
\text { sharing with friends and family; } \\
\text { reduced food costs }\end{array}$ & Strong \\
\hline $\begin{array}{l}\text { Spees et al. }{ }^{(33)} \\
2015 \\
\text { American Journal of } \\
\text { Health Behavior }\end{array}$ & $\begin{array}{l}\text { Central Ohio, } \\
\text { USA }\end{array}$ & $\begin{array}{l}\text { Define perception of health } \\
\text { behaviour changes in } \\
\text { cancer survivors } \\
\text { participating in an urban } \\
\text { gardening programme }\end{array}$ & $\begin{array}{l}\text { Observational, cross- } \\
\text { sectional study }\end{array}$ & 28 adult cancer survivors & $\begin{array}{l}\text { Perception regarding health } \\
\text { and behaviour changes }\end{array}$ & Focus groups & $\begin{array}{l}\text { Greater consumption of fresh } \\
\text { foods; exposure to foods not } \\
\text { previously tried; greater } \\
\text { interest in cooking; greater } \\
\text { planning of healthy meals; } \\
\text { reduced consumption of red } \\
\text { meat and ultra-processed } \\
\text { foods; greater opportunity to } \\
\text { consume a diet based on } \\
\text { vegetables }\end{array}$ & Strong \\
\hline
\end{tabular}




\begin{tabular}{|c|c|c|c|c|c|c|c|c|}
\hline $\begin{array}{l}\text { Data on publication } \\
\text { (authors, year of } \\
\text { publication and } \\
\text { journal) }\end{array}$ & Setting & Objective & Design & Participants & Outcomes investigated & $\begin{array}{l}\text { Outcome measurement } \\
\text { method }\end{array}$ & $\begin{array}{l}\text { Food-related outcomes in the } \\
\text { context of health promotion and } \\
\text { food security }\end{array}$ & $\begin{array}{l}\text { Quality } \\
\text { rating }\end{array}$ \\
\hline $\begin{array}{l}\text { Wakefield et al. }{ }^{\left({ }^{2}\right)} \\
2007 \\
\text { Health Promotion } \\
\text { International }\end{array}$ & $\begin{array}{l}\text { Toronto, ON, } \\
\text { Canada }\end{array}$ & $\begin{array}{l}\text { To identify impacts on health } \\
\text { of participation in CG }\end{array}$ & $\begin{array}{l}\text { Observational, cross- } \\
\text { sectional study }\end{array}$ & $\begin{array}{l}\text { 68-eight CG participants } \\
\text { (ages NR) }\end{array}$ & $\begin{array}{l}\text { Reasons for participating in } \\
\text { CG, benefits of CG, } \\
\text { gardening queries, food } \\
\text { and health, ways of } \\
\text { bringing together } \\
\text { organizations, researchers } \\
\text { and socially vulnerable } \\
\text { individuals }\end{array}$ & $\begin{array}{l}\text { Participant observation, focus } \\
\text { groups, in-depth } \\
\text { interviews, field notes }\end{array}$ & $\begin{array}{l}\text { Better access to fresh and healthy } \\
\text { foods; improvement in } \\
\text { nutrition; savings on food } \\
\text { costs; consumption of } \\
\text { culturally appropriate foods; } \\
\text { improved nutrition of children } \\
\text { and family; greater } \\
\text { consumption of vegetables; } \\
\text { growing of organic foods; food } \\
\text { sharing; knowledge on F\&V } \\
\text { and recipes }\end{array}$ & Moderate \\
\hline $\begin{array}{l}\text { Alaimo et al. }{ }^{(35)} \\
2008 \\
\text { Journal of Nutrition } \\
\text { Education and } \\
\text { Behavior }\end{array}$ & Flint, MI, USA & $\begin{array}{l}\text { To examine association } \\
\text { between participation of } \\
\text { members of the household } \\
\text { in gardens and F\&V } \\
\text { consumption }\end{array}$ & $\begin{array}{l}\text { Observational, cross- } \\
\text { sectional study }\end{array}$ & $\begin{array}{l}766 \text { individuals aged }>18 \\
\text { years living in urban areas }\end{array}$ & $\begin{array}{l}\text { Frequency of consumption of } \\
\text { fruit juice, other fruit, green } \\
\text { salads, potatoes (not } \\
\text { fried), green juice, yellow } \\
\text { or orangish vegetables, } \\
\text { beans and other } \\
\text { vegetables }\end{array}$ & $\begin{array}{l}\text { Interviews by telephone using } \\
\text { questionnaire }\end{array}$ & $\begin{array}{l}\text { Significantly greater consumption } \\
\text { of } F \& V \text { in exposure group }\end{array}$ & Moderate \\
\hline $\begin{array}{l}\text { Wills et al. }{ }^{(36)} \\
2010 \\
\text { Health Promotion } \\
\text { International }\end{array}$ & $\begin{array}{l}\text { Johannesburg, } \\
\text { South Africa }\end{array}$ & $\begin{array}{l}\text { To explore the potential of an } \\
\text { urban garden for } \\
\text { improving food security to } \\
\text { build assessment } \\
\text { indicators of the project }\end{array}$ & $\begin{array}{l}\text { Observational, cross- } \\
\text { sectional study }\end{array}$ & $\begin{array}{l}19 \text { adult participants } \\
\text { including NGO, } \\
\text { universities, gardening } \\
\text { and students }\end{array}$ & $\begin{array}{l}\text { Involvement in CG, creation } \\
\text { of CG, impact, difference } \\
\text { made by CG for them } \\
\text { personally and for the } \\
\text { organization they } \\
\text { belonged to }\end{array}$ & Running of workshop & $\begin{array}{l}\text { Greater access to vegetables, } \\
\text { harvest sharing, feeling of } \\
\text { making a difference to people's } \\
\text { health by giving away healthy } \\
\text { foods }\end{array}$ & Moderate \\
\hline $\begin{array}{l}\text { Litt et al. }{ }^{(37)} \\
2011 \\
\text { American Journal of } \\
\text { Public Health }\end{array}$ & $\begin{array}{l}\text { Denver, CO, } \\
\text { USA }\end{array}$ & $\begin{array}{l}\text { To analyse the relationship } \\
\text { between F\&V intake, } \\
\text { participation in gardens } \\
\text { and processes related to } \\
\text { living in the } \\
\text { neighbourhood }\end{array}$ & $\begin{array}{l}\text { Observational, cross- } \\
\text { sectional study }\end{array}$ & $\begin{array}{l}436 \text { adult individuals living } \\
\text { close to } C G\end{array}$ & $\begin{array}{l}\text { F\&V intake, participation in } \\
\text { gardens, physical activity, } \\
\text { self-rated health, BMI, } \\
\text { psychological and social } \\
\text { processes related to living } \\
\text { in the neighbourhood }\end{array}$ & Questionnaire & $\begin{array}{l}\text { Greater F\&V consumption among } \\
\text { CG participants }\end{array}$ & Moderate \\
\hline $\begin{array}{l}\text { Freeman et al. }{ }^{(38)} \\
2012 \\
\text { Journal of } \\
\quad \text { Environmental } \\
\text { Psychology }\end{array}$ & $\begin{array}{l}\text { Dunedin, New } \\
\text { Zealand }\end{array}$ & $\begin{array}{l}\text { To better understand the } \\
\text { relationship of individuals } \\
\text { with their gardens }\end{array}$ & Observational, cohort study & $\begin{array}{l}55 \text { adults with domestic } \\
\text { gardens }\end{array}$ & $\begin{array}{l}\text { Importance of the garden, its } \\
\text { use, activities, and } \\
\text { presence of native } \\
\text { species, birds and animals }\end{array}$ & $\begin{array}{l}\text { Questionnaires and } \\
\text { photographic records }\end{array}$ & $\begin{array}{l}\text { Use of garden area for meals; } \\
\text { vegetable growing associated } \\
\text { with connection to the Earth, } \\
\text { financial necessity, importance } \\
\text { of consuming pesticide-free } \\
\text { foods; environmental, social } \\
\text { and political commitment, and } \\
\text { strengthening ties with } \\
\text { neighbours through sharing } \\
\text { foods grown }\end{array}$ & Moderate \\
\hline $\begin{array}{l}\text { McMahan et al. }{ }^{(39)} \\
2014 \\
\text { Journal of Hunger \& } \\
\text { Environmental } \\
\text { Nutrition }\end{array}$ & lowa State, USA & $\begin{array}{l}\text { To assess perceptions, } \\
\text { attitudes and behaviour in } \\
\text { relation to gardening and } \\
\text { food security }\end{array}$ & $\begin{array}{l}\text { Observational, cross- } \\
\text { sectional study }\end{array}$ & $\begin{array}{l}855 \text { adult dwellers of urban } \\
\text { and rural areas }\end{array}$ & $\begin{array}{l}\text { Perception of gardening- } \\
\text { related issues: } F \& V \text { intake, } \\
\text { F\&V sharing, serving } \\
\text { meals made with F\&V to } \\
\text { others, buying foods at } \\
\text { producers' markets, } \\
\text { consuming home-grown } \\
\text { foods, planting F\&V, } \\
\text { growing own food }\end{array}$ & Questionnaire & $\begin{array}{l}\text { Experience with gardening was } \\
\text { significantly associated with } \\
\text { positive perceptions of } F \& V \\
\text { and growing foods }\end{array}$ & Weak \\
\hline
\end{tabular}

CG, community garden; HgA1c, glycated Hb; F\&V, fruit and vegetable; DG, domestic garden; NR, not reported; NGO, non-governmental organization. 
Table 2 Results reported by food-related outcome dimensions in the context of health promotion and food security

\begin{tabular}{llc}
\hline Category & Dimensions & References \\
\hline Healthy food & Increases in the amount & $29,31,33-35$, \\
practices & and variety of fruit and & 37,39 \\
& vegetables consumed & \\
& $\begin{array}{l}\text { Practice of a healthier diet } \\
\text { Improved nutrition of the }\end{array}$ & 29,33 \\
& family & 29,34 \\
Healthy food & Increasing access to & $28,30-32,34$, \\
access & healthy foods & 36,38 \\
& Sharing produce & $31,32,34,36,38,39$ \\
Healthy food & Reducing food cost & $32,34,38$ \\
beliefs, & Strengthened connections & 31,34 \\
knowledge and & with cultural roots & $30,32,34,38$ \\
attitudes & Production and & \\
& consumption of fresh & \\
& pesticide-free foods & $28,33,34,39$ \\
& Greater interest in cooking & and meal planning \\
& Knowledge on the & $29,30,33,34$ \\
& importance of healthy & \\
\hline
\end{tabular}

on this dimension addressed greater interest in cooking and meal planning ${ }^{(28,33,34,39)}$, knowledge on the importance of healthy eating ${ }^{(29,30,33,34)}$, production and consumption of fresh pesticide-free foods ${ }^{(30,32,34,38)}$ and strengthened connections with cultural roots ${ }^{(31,34)}$.

Weltin and Lavin ${ }^{(28)}$ reported greater interest in recipes and methods of preparing the foods grown. Blair et al. ${ }^{(29)}$ found that most participants reported that the experience had generally encouraged them to pursue a healthier diet and specifically to consume more vegetables, citing the importance of a healthy diet. Giraldo et al. ${ }^{(30)}$ reported that participants became knowledge multipliers within their families and communities. These authors also found assimilation of knowledge on the importance of daily consumption of vegetables as a protective factor against chronic non-communicable diseases and the application of the principles of urban agriculture to implement community and domestic gardens, without the use of products harmful to health, which are low cost and easy to set up. Hale et $a l^{(31)}$ reported that participants strengthened connections with cultural roots. According to Scott et al. ${ }^{(32)}$, one of the main benefits of the garden was better diet quality, and in particular the production of fresh pesticide-free foods. Outcomes reported by Spees et $a{ }^{(33)}$ addressed greater interest in cooking and experimenting in the kitchen, given the enhanced ability for planning healthy meals and greater ability of the participants to consume a diet based largely on vegetables. Wakefield et $a l^{(34)}$ highlighted greater consumption of culturally appropriate foods, growing of organic foods, knowledge on $\mathrm{F} \& \mathrm{~V}$ and recipes containing these foods. Freeman et $a l .{ }^{(38)}$ found that growing vegetables was associated with the importance of consuming pesticidefree foods, contact with the Earth and environmental, social and political commitment. Individuals interviewed by McMahan et $a l^{(39)}$ cited greater frequency of serving meals made with F\&V to others.

The studies of Alaimo et $a l^{(35)}$, Wills et $a l .{ }^{(36)}$ and Litt et al. ${ }^{(37)}$ did not report outcomes on healthy food beliefs, knowledge and attitudes.

\section{Population bealth status, study types and garden types}

Dividing the studies by population type revealed that three assessed individuals for health conditions ${ }^{(28,29,33)}$, whereas the remainder did not report the health status of participants. Outcomes related to 'healthy food practices' were reported more often in studies involving individuals with diseases. Outcomes related to 'healthy food access' were more reported in the remaining studies.

Stratifying studies by design type showed that four studies investigated urban gardens as study interventions $^{(28-30,33)}$ and the remainder examined the experience of individuals in existing gardens. Proportionally, more studies in the group involving pre-existing gardens reported outcomes in the 'healthy food access' category. Outcomes for 'healthy food beliefs, knowledge and attitudes' and 'healthy food practices' categories were reported more often among studies assessing interventions with urban gardens.

Dividing studies by urban garden type revealed that three assessed domestic gardens ${ }^{(29,32,38)}$ while the remainder analysed community gardens. Studies on community gardens investigated more outcomes in the 'healthy food beliefs, knowledge and attitudes' category. Outcomes related to the 'healthy food access' category were more frequently reported in studies analysing domestic gardens.

\section{Quality analysis}

The qualitative studies had better overall ratings than the quantitative investigations. The items of the COREQ checklist that contributed to low quality were related to omission of information on researchers, details about the data collection method, reference to data saturation, details on data analysis method and reference to participant feedback. For the quantitative studies, according to the National Institutes of Health instrument, the highest prevalence of non-compliance with criteria was related to measurement of previous exposure prior to measuring outcomes, measurement of level of exposure to gardens, and validity and reliability of measurements of exposure and of outcomes.

\section{Discussion}

The objective of the current review was to examine the impacts on food and nutrition-related outcomes as a result of participating in urban gardens by identifying positive associations with healthy food practices, healthy food 
access, and healthy food beliefs, knowledge and attitudes. Taken together, the studies included in the review provide important information on the relationship between participation in urban gardens and dietary outcomes.

It is important to point out the origin of the studies included in the review and the journals in which they were published. Of the twelve studies assessed, ten were conducted in high-income countries, with seven from the USA, one from Canada, one from Australia and one from New Zealand, and they were published predominantly in North American and European journals. Notably, one of the databases holds indexed journals from Latin America and the Caribbean (LILACS) and although the preliminary search retrieved five studies, none were included in the review for failing to meet the eligibility criteria.

Among the quantitative cross-sectional studies $(35,37,39)$, none investigated the level of exposure to urban gardens, for example the definition of the type of garden (community or domestic) and participation time or frequency, hampering the generalization of results. Given that cross-sectional studies preclude the establishment of causality relationships between participation in community gardens and dietary outcomes of participants, it cannot be inferred whether individuals consuming healthier diets had greater interest in participating in community gardens or whether community gardens modified participants' diets. All of the quantitative studies reported an increase in the amount and variety of F\&V consumed, whereas the other outcomes such as sharing of harvest and knowledge on the importance of a healthy diet were reported less often. Other outcomes, such as cost savings on food and valuing of pesticide-free foods, were not reported. Perhaps owing to the nature of quantitative investigations, which should employ instruments for measuring predefined variables, the outcomes of quantitative studies covered fewer dimensions than those of qualitative studies. While quantitative studies reported mostly outcomes related to the healthy food practices' category, the majority of outcomes reported by qualitative studies pertained mainly to the healthy food access' and 'healthy food beliefs, knowledge and attitudes' categories.

Eight studies used the qualitative approach ${ }^{(28,30-34,36,38)}$. Some of the studies did not set out to answer a pre-set question about dietary-related outcomes of participants; that information emerged spontaneously in reports when health benefits and behaviour changes were addressed, for example $(30-33,36,38)$. Qualitative studies are fundamental for investigations in the field of food and nutrition, mainly because of the possibility of elucidating subjective output while contextualizing food as a mediator of relationships, since eating is not a fully measurable physiological act but involves social, political, psychic and aesthetic relationships ${ }^{(40)}$.
The heterogeneity of settings, populations and assessment methods was high. In addition, the quality analysis of some studies indicated the need for greater methodological rigour. The methodological limitations reported in the current review had already been identified by previous reviews ${ }^{(20,21)}$. These limitations may be due, in part, to the complexity of the theme. In view of the inherent subjectivity involved in collecting and analysing qualitative data, transparency is needed when presenting some components to demonstrate the methodological rigour required. According to Tong et al. ${ }^{(26)}$, qualitative studies explore complex phenomena and can contribute with fresh knowledge and perspectives for health care, health policies and future studies. However, akin to quantitative studies, if poorly designed and with weak reporting of findings, qualitative studies may not be applicable in decision making ${ }^{(26)}$. Particularly, information on the researchers, the theoretical basis of analysis, details on the data collection setting, the process of analysing the material collected and data saturation discussions were frequently omitted.

Different types of studies and approaches were included to gather distinct feelings and meanings about food, although they did not present the objectivity of parameters typically considered when systematic reviews are made. Among all the studies included in the review, outcomes related to increasing access to healthy food ('healthy food access' category) were the most prevalent, followed by the 'healthy food beliefs, knowledge and attitudes' category and lastly by the 'healthy food practices' category. In fact, the process of promoting changes in dietary practices is complex and encompasses aspects such as beliefs, knowledge and attitudes. Among the 'healthy food access' category, the most reported dimension was perception of improved access to healthy foods $^{(28,30-32,34,36,38)}$, followed by harvest sharing ${ }^{(31,32,34,36,38)}$. With regard to 'healthy food beliefs, knowledge and attitudes', three dimensions were equally prevalent: assimilation of the importance of healthy food ${ }^{(29,30,33,34)}$, the valuing of cooking and planning healthy meals ${ }^{(28,33,34,39)}$ and the valuing of growing and consumption of organic foods ${ }^{(30,32,34,38)}$. Among the 'healthy food practices' category, the most reported dimension was greater consumption of $\mathrm{F} \& \mathrm{~V} /$ fresh foods and more varied diet ${ }^{(29,31,33-35,37,39)}$.

The fact that the 'healthy food practices' category featured more strongly in studies involving patients is congruent with the expectation that these individuals will change their dietary practices to exert a positive impact on their health conditions. Thus, it can be assumed that the actions implemented had this goal.

In the case of studies assessing domestic gardens, the issue of 'healthy food access' is closer, more relevant, readily achieved, perceived and reported. In community gardens, there is generally involvement of a larger number of individuals and greater likelihood of addressing aspects pertaining to the 'healthy food beliefs, knowledge and 
attitudes' category, whereas access is reported less often because it is not necessarily sufficient.

The results also confirmed that the most recurrent focus of interventions in the food and nutrition-related area centred on the expectation of changes in dietary practices. This was evidenced by the greater presence of 'healthy food beliefs, knowledge and attitudes' and 'healthy food practices' categories in studies involving interventions than in those on pre-existing gardens.

Food behaviour is extremely complex and the product of interaction of multiple factors at individual (personal factors, such as motivation, expectations and self-reliance), social (networks, such as friends, family members and community), environmental (places where individuals consume or acquire food) and macro (more distal determinants such as food production and supply, prices and agricultural policies) levels ${ }^{(41)}$. Adequate and healthy food in the context of food security and health promotion goes beyond the bounds of biomedical concepts that mainly assess the constituent nutrients of foods. Food is culturally and socially constructed and a basic human right; moreover, it is influenced by determinant processes relative to social aspects, access, the environment and food systems $^{(23,24,42)}$. In this respect, the findings of the present review confirm that interventions, such as urban gardens, are able to exert an impact on determinant processes at different levels and provide support for healthy choices, making them available and accessible to individuals.

\section{Limitations}

The present review has some limitations. First, the fact that the population studied comprised adults, which is a life stage that includes ages that differ in many aspects, may limit the interpretation of findings. Gardens may have different meanings and importance to people at different life stages or in different circumstances. Another limitation is the fact that both domestic and community gardens were included, two formats that have specific characteristics. Another limitation is the fact that the cut-off points adopted to attribute the concepts of strong, moderate and weak ratings to the studies were defined by the authors owing to the lack of consensus in the literature on this issue. However, various combinations of terms were employed on the relevant databases in a bid to retrieve as many studies as possible.

\section{Conclusions}

Based on the current review, the food and nutrition outcomes in adults who participate in urban gardens are promising. Analysis of the experiences with urban gardens revealed thematic patterns relative to adequate and healthy food in the context of food security and health promotion, such as greater F\&V consumption, perception of improved access to healthy foods, harvest sharing, improved family diet, assimilation of the importance of adequate and healthy food, valuing of cooking and of planning healthy meals, and valuing of growing and consumption of organic foods. Although some studies indicated the need for greater methodological rigour, it is evident that participation in urban gardens, whether domestic or community, has a positive impact on important healthy food practices, access, and beliefs, knowledge and attitudes. The studies included in the present systematic review indicate that community interventions may produce changes in beliefs, knowledge and attitudes and can show broader reach and sustainability, by triggering the willingness for healthier food practices. Long-term studies on community gardens with these characteristics will be able to verify, by following more rigorous methodological aspects, the repercussions of changes in this direction; this will aim at indicating whether changes in beliefs, knowledge and attitudes can change practices, which is the expectation of results on healthy eating.

\section{Acknowledgements}

Acknowledgement: The authors thank the São Paulo Research Foundation (FAPESP) for the financial support. Financial support: This manuscript was supported by FAPESP (grant number 2012/21730-4). FAPESP had no role in the design, analysis or writing of this article. Conflict of interest: None. No financial disclosures were reported by the authors of this paper. Authorship: M.T.G. was involved in formulating the research questions, designing the study, carrying it out, analysing and interpreting the data, and elaborating the manuscript. S.M.R. was involved in carrying out the study, interpreting the data and the article revision. A.C.C.G.G. was involved in article revision C.M.B. was involved in formulating the research questions and article revision. All authors approved the final version for publication. Ethics of buman subject participation: Not applicable.

\section{Supplementary material}

To view supplementary material for this article, please visit https://doi.org/10.1017/S1368980017002944

\section{References}

1. Wang X, Ouyang Y, Liu J et al. (2014) Fruit and vegetable consumption and mortality from all causes, cardiovascular disease, and cancer: systematic review and dose-response meta-analysis of prospective cohort studies. BMJ 349, g4490.

2. Monteiro CA, Levy RB, Claro RM et al. (2011) Increasing consumption of ultra-processed foods and likely impact on human health: evidence from Brazil. Public Health Nutr 14, 5-13. 
3. Kamphuis CB, Giskes K, de Bruijn GJ et al. (2006) Environmental determinants of fruit and vegetable consumption among adults: a systematic review. BrJ Nutr 96, 620-635.

4. Boeing H, Bechthold A, Bub A et al. (2012) Critical review: vegetables and fruit in the prevention of chronic diseases. Eur J Nutr 51, 637-663.

5. World Health Organization (2003) Diet, Nutrition and the Prevention of Chronic Diseases. Joint WHO/FAO Expert Consultation. WHO Technical Report Series no. 916. Geneva: WHO.

6. Hall JN, Moore S, Harper SB et al. (2009) Global variability in fruit and vegetable consumption. Am J Prev Med 36, 402-409.

7. Walter P (2013) Theorising community gardens as pedagogical sites in the food movement. Environ Educ Res 19, 521-539.

8. Levkoe CZ (2006) Learning democracy through food justice movements. Agric Hum Values 23, 89-98.

9. Sommerfeld AJ, Waliczek TM \& Zajicek JM (2010) Growing minds: evaluating the effect of gardening on quality of life and physical activity level of older adults. HortTechnology 20, 705-710.

10. Shiue I (2016) Gardening is beneficial for adult mental health: Scottish Health Survey, 2012-2013. Scand J Occup Ther 23, 320-325.

11. Teig E, Amulya J, Bardwell L et al. (2009) Collective efficacy in Denver, Colorado: strengthening neighborhoods and health through community gardens. Health Place 15, 1115-1122.

12. Harris N, Minniss FR \& Somerset S (2014) Refugees connecting with a new country through community food gardening. Int J Environ Res Public Health 11, 9202-9216.

13. Ribeiro SM, Bógus CM \& Watanabe HA (2015) Agricultura urbana agroecológica na perspectiva da promoção da saúde. Saude Soc 24, 730-743.

14. Grabbe L, Ball J \& Goldstein A (2013) Gardening for the mental well-being of homeless women. J Holist Nurs 31, 258-266.

15. Costa CGA, Garcia MT, Ribeiro SM et al. (2015) Hortas comunitárias como atividade promotora de saúde: uma experiência em Unidades Básicas de Saúde. Cienc Saude Colet 20, 3099-3110.

16. Machado AT \& Machado CTT (2002) Agricultura Urbana. Planaltina, DF: Embrapa Cerrados.

17. Ganann R, Fitzpatrick-Lewis D, Ciliska D et al. (2014) Enhancing nutritional environments through access to fruit and vegetables in schools and homes among children and youth: a systematic review. BMC Res Notes 7, 422.

18. Berezowitz CK, Bontrager Yoder AB \& Schoeller DA (2015) School gardens enhance academic performance and dietary outcomes in children. J Sch Health 85, 508-518.

19. Davis JN, Spaniol MR, Somerset S (2015) Sustenance and sustainability: maximizing the impact of school gardens on health outcomes. Public Health Nutr 18, 2358-2367.

20. Robinson-O'Brien R, Story M \& Heim S (2009) Impact of garden-based youth nutrition intervention programs: a review. J Am Diet Assoc 109, 273-280.

21. Masset E, Haddad L, Cornelius A et al. (2012) Effectiveness of agricultural interventions that aim to improve nutritional status of children: systematic review. BMJ 344, d8222.

22. Santos CMC, Pimenta CAM \& Nobre MRC (2007) A estratégia PICO para a construção da pergunta de pesquisa e busca de evidências. Rev Latino-Am Enfermagem 15, 508-511.
23. Pinheiro ARO (2005) A alimentação saudável e a promoção da saúde no contexto da segurança alimentar e nutricional. Rev CEBES Saude Debate 29, 125-139.

24. CONSEA Nacional (2007) GT - Alimentação Adequada e Saudável. Relatório Final. Brasília, DF: Ministério da Saúde.

25. Brasil, Ministério da Saúde (2012) Política Nacional de Alimentação e Nutrição. Brasília, DF: Ministério da Saúde.

26. Tong A, Sainsbury P \& Craig J (2007) Consolidated criteria for reporting qualitative research (COREQ): a 32-item checklist for interviews and focus groups. Int J Qual Health Care 19, 349

27. National Institutes of Health (2014) Study Quality Assessment Tools. http://www.nhlbi.nih.gov/health-pro/guide lines/in-develop/cardiovascular-risk-reduction/tools (accessed January 2016).

28. Weltin AM \& Lavin RP (2012) The effect of a community garden on $\mathrm{HgA1c}$ in diabetics of Marshallese descent. J Community Health Nurs 29, 12-24.

29. Blair CK, Madan-Swain A, Locher JL et al. (2013) Harvest for health gardening intervention feasibility study in cancer survivors. Acta Oncol 52, 1110-1118.

30. Giraldo SLH, Torres AP, Cárdenas LM et al. (2012) Promoción de una alimentación saludable: experiencia en Tunja, Colombia. Av Enferm XXXX, 55-63.

31. Hale J, Knapp C, Bardwell L et al. (2011) Connecting food environments and health through the relational nature of aesthetics: gaining insight through the community gardening experience. Soc Sci Med 72, 1853-1863.

32. Scott TL, Masser BM \& Pachana NA (2014) Exploring the health and wellbeing benefits of gardening for older adults. Ageing Soc 10, S0144686.

33. Spees CK, Joseph A, Darragh A et al. (2015) Health behaviors and perceptions of cancer survivors harvesting at an urban garden. Am J Health Behav 39, 257-266.

34. Wakefield S, Yeudall F, Taron C et al. (2007) Growing urban health: community gardening in South-East Toronto. Health Promot Int 22, 92-101.

35. Alaimo K, Packnett E, Miles RA et al. (2008) Fruit and vegetable intake among urban community gardeners. J Nutr Educ Behav 40, 94-101.

36. Wills J, Chinemana F \& Rudolph M (2010) Growing or connecting? An urban food garden in Johannesburg. Health Promot Int 25, 33-41.

37. Litt JS, Soobader MJ, Turbin MS et al. (2011) The influence of social involvement, neighborhood aesthetics, and community garden participation on fruit and vegetable consumption. Am J Public Health 101, 1466-1473.

38. Freeman C, Dickinson KJ, Porter S et al. (2012) 'My garden is an expression of me': exploring householders' relationships with their gardens. J Environ Psychol 32, 135-143.

39. McMahan M, Richey EJ \& Tagtow A (2014) Cultivating food security: low-resource Iowans' perspectives on food gardening. J Hunger Environ Nutr 9, 299-317.

40. Bosi MLM, Prado SD, Lindsay AC et al. (2011) O enfoque qualitativo na avaliação do consumo alimentar: fundamentos, aplicações e considerações operacionais. Rev Saude Colet 21, 1287-1296.

41. Story M, Kaphingst KM, Robinson-O'Brien R et al. (2008) Creating healthy food and eating environments: policy and environmental approaches. Annu Rev Public Health 29, 253-272.

42. Brasil, Ministério da Saúde (2014) Guia Alimentar para a População Brasileira, 2nd ed. Brasília, MF: Ministério da Saúde. 